\title{
UMA PORTA FECHADA AO DEVANEIO: uma aplicação a textos sânscritos dos esquemas de abordagem lingüístico-retórica de Isaac Nicolau Salum
}

\author{
Carlos Alberto da Fonseca
}

(FFLCH-USP)

\section{Abstract}

In four articles issued between 1971 and 1975, Isaac Nicolau Salum outlined the main ideas of a "linguistic-rhetorical approach" method to texts not giving it a definitive form, which was, however, tried to be attained by means of inumerable text schematization exercises published in eleven booklets up to 1979.

Rescuing some of the scattered proposals in those writings, this article aims at meditating about the method value for a critical study of texts and for the analysis of the speech, and at the same time, as a corroboration of the procedure eflectiveness, applying it to the characterization of Nala and Damayant, characters of a parallel account to the narrative structure of the Sansknit epic poem Mahäbhärata, for whom it reveals rhetorical dimensions that a less attentive reading will neglect. 
O thulo deste artigo ê o refazimento de uma expressáo com que, na conclusấo do seu "Camós em três lances", Isaac Nicolau Salum afirma que o método de abordagem lingülstico-retórica de textos por ele proposto, "levando a uma penetraçăo mais profunda no texto, libera o docente do impressionismo crtico, que é o domínio do 'vale-tudo', uma porta aberta ao devaneio"1. Essa afirmaçăo/citaçăo é exemplar como definiçăo das finalidades dessa sua proposta de análise textual: minha intençăo é, respigando aqui e ali nos escritos do Mestre, possibilitar a interessados na ciência da linguagem uma pequena e rápida amostragem do que pode produzir um esplrito cientffico sério $\theta$ cauteloso - e obstinadamente humilde - como o do estudioso em tela; $\theta$, também, revelar uma pequena parcela da modemidade cientffica latente nos seus exercicios de esquematização de textos, nos arrazoados teóricos que elaborou e neles dispersa/imersa na especial atençăo dada à historia do método e à fixaçáo de critérios metodológicos para a técnica por ele desenvolvida².

Em primeiro lugar, o material explfcito de trabaho é o texto, considerado, primeiramente, como "um enunciado ou uma sucessão de enunciados"3, e, depois, como "uma sucessăo de frases (= perlodos) coordenadas ou justapostas, podendo estar em relação de subordinação semântica, mas não de subordinação sintática", admitida esta última apenas no plano intrafrásico ${ }^{4}$. É evidente que essa terminologia, proveniente da boa gramática tradicional, se deixa de bom grado reformular pela terminologia e pela conceituação da Lingülstica moderna - mas năo é essa a proposta deste artigo. Desde o começo, o próprio ensejador deste método de abordagem considera que "claro está que al nos achamos antes no domínio da fala que no da lingua" 5 . Dessa maneira, o texto, considerado como sucessão de unidades semanticamente subordinadas, dá-se ao seu analista como um ato de fala: "a interpretaçáo do texto é tratamento da fala"6, aquela manifestação individual e momentânea de que fala Saussure no Cours de linguistique génêrale.

Como o próprio I. N. Salum parece observar ${ }^{7}$, os seus princlpios de esquematização do texto não levariam à "estrutura profunda" da lingua (estrutura que, na realidade, desvenda os pormenores da língua), mas, sim, ao exame do que a fala tem de estruturalmente significativo no seu fundo tecido em forma de enunciado revelador das. idiossincrasias do falante (= autor de um texto). É certo que, no texto, "os perfodos săo enunciados coordenados, os parágrafos são uma sucessão de perlodos coordenados, os capitulos uma sucessåo de parágrafos coordenados"8 - mas essa afirmaçáo pare-

1 - Salum 1971: 177.

2 - Até outubro de 1979, 11 Cademos publicados, 4 artigos (ver bibliografia) e incontáveis esquemas avulsos.

3-Salum 1971: 3; Salum 1972: 3; Salum 1972: 3.

4 - Salum 1978: Il; Salum 1979: Ill. Salvo informaçరes em contrário, os grifos sâo sempre meus.

5-Salum 1971: 2: Salum 1972: 2; Salum 1972: 2.

6 - Idem.

7 - Salum 1978: III.

8 - Salum 1971: 2; Salum 1972: 2: Salum 1972: 2. 
ce querer dizer, justamente, do conjunto das unidades textuais significativas com as quais o falante elabora Kgica e retoricamente o seu discurso. $E$, nesse sentido, năo corresponde essa afirmaçáo a um principio de tipologia dos instantes organizadores da fala?

Em segundo lugar, o campo de destinaçăo do trabalho desenvolvido por I. N. Salum está longe de ser apenas o dídático, aquele que se dá com o contato entre docente $\theta$ discente. $O$ certo, antes, $\theta$ que a relativa simplicidade de seus principios de esquematização do texto tem como escopo uma performáncia discente levada a cabo sem maiores problemas (ela costuma ocorrer com a ausencia do docente) senáo os da compreensăo de conceitos gramaticais. Em outras palavras, o que se exige do discente - ele próprio um falante - é que ele aplique analiticamente a uma fala de outrem os seus proprios meios de estruturaçáo de um texto. A empatia é perfeita, e mediada pela gramáti$\mathrm{ca}-\theta$ justamente por aquelas instáncias da gramática que parecem dizer respeito mais à fala do que à lingua. Por essa razáo, ultrapassando-se a situaçáo dídática, esse mé todo de abordagem de um texto pode levar, no plano académico-intelectual, ao estabelecimento de uma Lingülstica da Fala - ou de uma das suas possibilidades -, campo analfico proposto por Saussure (e para o qual o próprio lingüista parecia se dirigir com o seu estudo mal-compreendido dos anagramas).

Muito preso ainda à situação didática, I. N. Salum afirma que o seu método libera o docente do "impressionismo" crítico - $\theta$ os seus esquemas de exegese já foram chamados de, "de certo modo, uma profanação da poesia"9 . Bem, mas ’ $\alpha$ vó $\lambda v \sigma \iota s$ quer dizer isso mesmo": "liberação" - que neste caso é dupla: liberaçăo da forma significativa do texto, $\Theta$ do docente (e nåo sơ dele) para o que é cientificamente sério; também, "dissoluçăo, fim, morte" - mas apenas daquele lirismo espumoso, da espuma de sentido que recobre o texto, para dar lugar ao surgimento do que ele tem de efetivamente p. o é t i c o, de construção; e, ainda, "soluçăo" - o que parece evidente: a constatação do lirismo é redundante, reflexo de espelho no espelho, prolongamento da imagem ao infinito, o que não acontece com a verificaçăo do p o e t i c o do texto, que tem grau ótimo de informaçăo e reflete apenas o objeto e dele dá apenas uma imagem. Há alguma demonstraçáo melhor do labor $p$ o é t i c o do exórdio d'Os Lusladas que seja táo visualmente cabal e esclarecedora do texto camoniano do que os quadros exegéticos de "Camóes em três lances" que, eliminando 0 lirismo tout court grandiloqüente dos comentários desdobradores, apresenta 0 p o e t l c o aprisionado pela análise logicamente dirigida $\theta$ indliciador do labor do poeta?

Essas consideraçбes têm sua pertinência aumentada quando se pensa no caráter interdisciplinar ensejado pela terceira fase desse processo de abordagem lingülstico-retórica do texto, aquela que corresponde a uma "reflexáo critica sobre o texto esquematizado"'11 que, segundo o próprio I. N. Salum, "ressaltará a interrrelaçáo

9 - Salum 1978: III.

10 - Pabón S. de Unina 1980: S.v.

11 - Salum 1971: 3; em Salum 1979: III, especificada como "análise critica exegética". 
sintático-semântica do texto, englobando consideraçoes de natureza maltipla, incluindo as históricas, mitológicas, psicologicas, sociologicas, retóricas, fonologicas $\theta$ ritmicas, tudo isso sem sair do texto, ou antes, saindo precisamente do texto"12. Continuando com as palavras do autor, "claro está que nesse caso salmos dos domínios da Lingülstica e entramos nos da Estillstica e no problema da exegese, do exame do contexto, da explicaçăo sterária, que 6 trabalho árduo, mas importante e fecundo"13. Por minha parte, considero essa re-inserçăo do objeto na sua própria situaçáo de enunclaçăo uma das maiores, senăo a maior delas, contribuiçøes do método para o avanço da ciência da linguagem - uma instância què, sem pretender substituir ou deslocar os estudos da língua, se preocupa em apanhar o falante dentro do próprio fomo em que ele coze seu discurso.

Se - para concluir esta introdução - aos olhos de alguns parece "crime" o fato de se dilacerar um texto para compreendé-lo racionalmente, que nos satisfaça e recompense o espirito a certeza de que o texto năo será mais algo etéreo passível de flutuaçס̃es e veleidades pessoais (a partir de que ponto, e até quando, se pode ignorar 0 texto em suas especificidades?), mas um terreno seguro sobre o qual se pisa com a sensaçăo de proteçăo oriunda da própria simplicidade do método de trabalho e sobre o qual se descobre o lado mais exacerbadamente humano da linguagem. $O$ que "compensa" o "crime" náo é tanto sua aparente simplicidade de processo, mas sua faceta outonal - tanto em relação à anatomização do texto. (sua radiografia, o espectro de árvore sem pormenores de fronde ${ }^{14}$ ), quanto, principalmente, em relaçăo à frutificação do texto e do método (a colheita da fala, o homem em seus interesses lingülsticos básicos e leg(timos) ${ }^{15}$.

A consideração do texto como fala, a teorização possivel de uma prática, a cientificidade do procedimento metodológico e a atençăo para os dados conceituais - foram esses os elementos que me fizeram pensar na possibilidade de descobrir em camadas mais profundas do falante sânscrito um elemento qualquer da sua ideologia. Acostumado que já estava ao manejo do conto "A História de Nala", do livro Ili do Mahābhārața, decidi-me por aplicar o método de abordagem lingüistico-retórica à caracterizaçăo de suas duas personagens principais ${ }^{16}$. O resultado a que cheguei pode parecer simples,

- 12 - Salum 1972: 3; grifo do Autor. "saindo".

13 - Salum 1973: 1.

14 - Idem.

15 - Refiro-me aqui, essencialmente, a Salum 1971: 3-4: “(...) a esquematizaçăo dispensa terminologia e poe tudo diante dos olhos. É esse o seu defeito: pondo tudo claro, parece excessivamente terra-a-terra,mas devo confessar que, se o desfrasamento nem sempre oferece dificuldades, a recomposiçáo às vezes atordoa a gente. Mas é um 'crime' que compensa!"

16 - Existe em português uma traduçăo de Luls Jardim publicada pela José Olympio em 1944 como volume 12 de sua Coleçâo Rubáyát com o tfulo de Nalá e Damayantl Procede da traduçáo/recriaçáo de A. - Ferdinand Herold (embora nâo refira essa fonte), publicada pela Édition d'Art H. Piazza em 1923, Paris, editada pela Imprimerie G. Kadar com um luxo que nossa José Olymplo eliminou por completo. O relato está também no Mahabharata de Annibal Mello de Noronha e Faro (Sáo Paulo, Qultura, 1943). pp. 77- 102, e na versấo de William Buck, com o mesmo ifulo (Sáo Paulo. Cĺrculo do Livro, 1988 ), pp. 125-140. 
mas ele aponta, graças ao método utilizado, uma direçáo nova na consideraçáo da instauraçáo do homern e da mulher sânscritos (talvez do homem e da mulher indlanos em geral, ou talvez apenas do homem $\theta$ da mulher épicos) naquela cultura $\theta_{\text {; }}$ em conseqüência, na sua literatura - no "textemunho" do homem sânscrito.

Os dois fragmentos destacados para a análise encontram-se no capfulo 52 do it vro acima referido $\theta$ săo constituídos pelos dlsticos 1-4, para a caracterizaçăo de Nala, e 10-14 para a de Damayantí. A esquematizaçăo, que segue de perto os principios gerais enunciados por I. N. Salum, foi feita para que se pudesse demonstrar pelo menos duas maneiras - aquelas que vêm expressas pelos textos - pelas quais o homem "falante" do padrăo literário da . Ingua indiana (ao qual se tem dado o nome de "sânscrito") construiu seus referentes. Em relaçáo à caracterização do rei Nala, esclareço que a recomposiçăo do texto poderia levar ao estabelecimento de vários esquemas diferentes, dependentes todos eles de critérios diversificados de agrupamento dos atributos: fica aqui consignada, no entanto, apenas uma dessas possibilidades - nenhuma das outras prejudicaria a argumentaçăo que se segue.

Eis os excertos ${ }^{17}$ :

a) para Nala:

àsid räjā nalo nāma virasenasuto balì $\mid$ upapanno gunai iștaí rūpavān açvakovidaḥ ll 11 l atișthan manujendrānām mürdhni devapatir yathāl upary upari sarveșäm äditya iva tejasā 112 | | brāhmanyo vedavic chüro nisadhesu mahīpatih 1

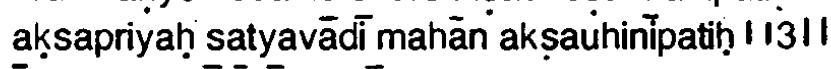
ipsito naranārinām udārah samyatendriyah rakṣitā dhanvinām çreșţhạ̣ sākṣād iva manuḥ svayam | | 4 ||

b) para Damayanti:

damayantỉ tu rüpena tejasā yaçasā çriyā saubhägyena ca lokeṣu yaçậ prapa sumadhyamā \|10\| atha tām vayasi prāpte dāsinām samalaminktam çatam çatam sakhĩnām ca paryupāsac chacìm iva $\mid 1111$ |l tatra sma rājate bhaimi sarvābharaṇabhüşitā I sakhīmadhye 'navadyāngi vidyut saudāmani yathā || 12|| ativa rüpasampannā çrír ivāyatalocanāi na deveșu na yakṣeșu tādṛ rūpavati kva cit I I13 II manuşeşv api cānyeşu drş̧apurvātha vā çrutā cittapramāthini bālā devānām api sundar̃ I 114 II.

Todos os historiadores da India, antiga ou moderna - e em sua esteira todos os estudiosos da cultura sânscrita -, săo unânimes em afirmar a inferioridade ocupada pe-

17 - Lanman 1947: partel. 
la mulher naquela cultura ao longo de toda sua travessia historica. Baselam-se eles, unicamente, no conteádo de toda a literatura jurddica, no conteádo das inscriçoes imperiais, no conteádo da imensa tradiçăo oral de cunho jurfdico que ainda hoje deságua na consideraçăo da inferioridade quase servilizada da mulher. Surge, no entanto, um impasse quando se verifica o contefido da literatura artística, em que a mulher comparece idealizada, alçada a uma posiçáo menos inferior do que aquela que se depreende dos textos, por assim dizer, legais. Instaura-se, assim, o mito puramente académico da "ambigüidade social da mulher indiana antiga", mito alimentado pelo exame apenas do conteúdo dos textos. O que os historiadores năo verificaram é que essa "ambigüidade" já está dada, para o perlodo épico pelo menos, na própria elaboração da forma de certos discursos sânscritos, entre os quais o analisado aqui se destaca. Em outros termos: o que eles năo perceberam - talvez por não julgarem ser a forma do texto um objeto de verificaçăo de sua área - é que, mais uma vez, forma e conteúdo não săo absolutamente separáveis. O que é preciso estabelecer, no entanto, é aquilo que marca textualmente essa adesão estrita, $\hat{\varepsilon}$ aquilo que faz a forma homologar textualmente um conteúdo da estrutura da sociedade e como o faz: Nesse sentido é que são preciosas as caracterizaçőes das personagens épicas.

No conto que relata a história de Nala e Damayanti, foi esta que o escolheu para marido numa fila de pretendentes; ao final, quando se reencontraram, ela estendeu os braços para ele e, aconchegando ao peito a fronte do marido, sorriu. $E$ ele chorou. De prazer, diz o texto, mas o certo é que, quando eles se separaram, foi Nala quem abandonou a esposa na floresta, com apenas meio manto de cortiça para proteger o corpo contra as intempéries. $E$, depois de ter fugido levando a outra metade do manto, enquanto Damayanti dormia, Nala se eclipsa da narrativa, que passa a relatar apenas os dissabores experimentados pela bela mulher às voltas com uma serpente, um caçador inebriado pela visão do seu corpo seminu, o calor do sol e o frio da noite, a fome, uma manada de elefantes em correria pela floresta, a cólera dos mercadores que a queriam apedrejar e a zombaria das crianças que a tomam por louca, até que é conduzida a uma rainha e recambiada à casa paterna. Guardava ela a certeza de que Nala voltaria um dia e se reuniria a ele, contrito e arrependido por náo acreditar que ela seria suficientemente forte para suportar com ele o exflio na floresta. Quanto a Nala, chora durante todo o perlodo de separaçăo; chora ainda quando, disfarçado em cocheiro, entra no palácio da esposa $\theta$ ali vê seus dois filhos; reencontrada a fêmea, Nala, o macho, pode, depois de chorar de prazer, fazer valer toda sua força e reconquistar o reino perdido num jogo de dados.

Ora, parece evidente que o conteúdo da narrrativa $\Theta$ construldo exatamente para radicar o valor ético fundamental da esposa indiana idealizada pelas castas dominantes, especialmente a esposa kșatriya - a fidelidade e a constância em qualquer circunstáncia. Ao mesmo tempo, para estabelecer a integralidade moral (dada como natural) do marido - mesmo que este tenha passado (ou até por isso mesmo) para segundo plano e mesmo que ele padeça do "demónio do jogo de dados" - uma prática recriminada, mas generalizada - que o leva a perder o reino. $O$ que é importante ressaltar, 
mais uma vez, é que todos os elemento éticos - masculinos e femininos - sáo fomecidos de antemăo, na caracterizaçăo das personagens, formalmente e náo apenas conteudisticamente.

O processo da construçăo enunciada das personagens efetuado de duas maneiras diferentes. Nala é caracterizado por meio de 21 atributos que se coordenam assindeticamente para dar ao leitor/ouvinte a configuraçăo global do marido-macho-herói $-\theta$, como tal, podem ser retirados sem que a narrativa perca nenhuma informaçăo fundamental. Damayanti, por outro lado, $\theta$ caracterizada de maneira mais complexa: em sua pintura inicial percebem-se blocos atributivos que săo tributários de um estatuto formal completamente diferente do de Nala: a esposa-fémea-herolna existe enquanto discurso, da mesma forma que, no desenvolvimento narrativo, ele só existe apenas enquanto rei; Damayantí - e esse nome é nela uma essencialidade - vale por seu caráter total.

Os atributos do "rei" são meras cristalizações estereotipadas e remetem, sempre, a conceitos facilmente perceptiveis no conjunto das qualidades necessárias a um símbolo dos ksatriya, os membros da segunda casta indiana (Ver esquemas $1.1 \theta$ 1.2). As comparaçōes estabelecidas com divindades (Indra, o "senhor dos deuses"; Āditya, o Sol; Manu, o legislador "visivel" na organização social) săo sempre apêndices: ao rei, basta-the estar acima e à frente de todos os homens $\theta$ que sua presença seja marcante - qualidades, aliás, não especfficas do rei em questão, mas "naturais" de qualquer rei. Assim, de maneira geral, todo o conjunto de atributos seria perfeitamente descartável - ao ouvinte/leitor bastaria saber que "existia um rei". Mas por que, então, alinhar todos os 21 atributos, enunciados caoticamente e mais ou menos agrupáveis em unidades menores relativas a físico, psicologia, moral, habilidades, etc.?

Já em relação a Damayantí, os atributos enunciam ou a exacerbação da beleza ffsica (que vai de "bela" a "linda", com freqüentes alusőes à "beleza") ou a agitação estabelecida na Corte ao seu redor (Ver esquemas 2.1 e 2.2). As comparaçōes com divindades (Çaci, a Força, esposa de Indra; Çri, a Boa-Sorte, a Fertilidade) são fundamentais: é necessário que ela esteja cercada de escravas e aias como Çaci e que tenha olhos amendoados como Çri para que, na narrativa, sejam realçados sua solidáo $e$ seu depauperamento físico. Assim como e fundamental que o primeiro e o último blocos de atributos se refiram mais especificamente à sua beleza e que os três blocos intermediários a situem progressivamente no palácio, no reino e no espaço do esplrito e da

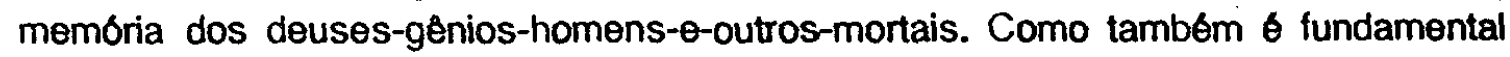
que sua beleza (no primeiro bloco) se espalhe em gloria por todas as terras e que a mulher (no último bloco) continue pertubando até o esplrito dos déuses no céu. O mais essencial, todavia, é que esses elementos não possam ser retirados, tornados atributos descartáveis com prejulzo da própria existência da personagem. Mas fica ainda uma pergunta: por que caracterizá-la com essa forma?

Devo, antes de mais nada, lembrar que as personagens se chamam Nala $\theta$ Damayanti $\theta$ que esses nomes sáo significativos. O termo nala designa uma espécie de caniço, aquele vegetal que o vento castiga e dobra. Por seu turno, Damayantī significa "vitoriosa". 
Em conseqüencla, parece-me que os nomes escolhidos estăo profundamente ligados às caracterizaçoes - melhor, as caracterizaçбes possibilitam, a partir dos nomes, a formaçăo de uma imagem que se deve cristalizar no esplrito do ouvinte/leitor desde o inf́cio. Nala, o rei chamado CANIÇO, deve ser imaginado desde o inf́cio (seu nome é o primeiro atributo enunciado) como o caniço em plena vitalidade, crescendo forte e poderoso no reino de Nisadha, com caracterlsticas pessoais genéricas de todos os reis, de todos os sustentáculos do reino. No desenvolvimento da narrativa, ele será batido pelo vento $\theta$ abatido pela tempestade que se desencadeará sobre sua vida e a de sua esposa: será uma personagem latente - um "rei" eclipsado, mas presente na ausência. Findos a tormenta $\theta 0$ tormento, ele recobrará sua vitalidade e seu poder no mesmissimo Nișadha. Veja-se, porém, que o eclipsamento do rei obriga a que o autor demonstre seus atributos apenas antes do motivo que levará a mulher ao primeiro plano narrativo. Tudo se passa como se, no fragor da tempestade, o caniço não fosse visivel, mas se tivesse a certeza de que ele continua existindo latentemente sob os elementos. Daf o autor marcar o rei, definitivá-lo antecipadamente com todos os atributos num enunciado adversativo e ambíguo (que será desenvolvido pela narrativa): o rei em questão é um caniço - mas é forte e isso basta.

Por outro lado a mulher chamada VITORIOSA tem, na sua caracterização, apontadas qualidades que fixam uma vitoria sobre a beleza de todas as outras mulheres e sobre $o$ ambiente das outras mulheres (e nisso ela semelha deusas) e sobre o espirito de toda classe de homens. Mas veja-se que sua vitória é apenas sobre o resplendor e os faustos genético e cortesão. Ao assumir o primeiro plano da narrativa, ela proclamará sua vitória sobre todas as intempéries morais, psicológicas, éticas, sociais, etc., conquistando, assim, seu lugar de direito ao lado do homem - sua vitória sobre a realidade -, mas via discurso: a conquista da consideração social quanto à parte da mulher como ser humano é uma operação pessoal, ativa - que tem como ponto de partida o fato de realmente possuir alguns dotes pessoais ${ }^{18}$. Se a inulher-fortaleza fosse enunciada no início da narrativa, isso daria de antemão a equalização da mulher; se, por outro lado, sua caracterização fosse feita com termos descartáveis, a simples enunciação da existência de uma mulher (chamada Vitoriosa ou não) não seria útil para a demonstração da complexidade (da "ambigüidade") da posiçáo da mulher que o texto quer, formalmente, ensejar e ressaltar em contraposição aos textos legais. Que ela se dé como vitoriosa é tăo importante para a narrativa quanto, fundamentalmente, para sua caracterização: dal seu nome não ser um atributo inicial, dal ele jâ aparecer "em discurso"; dal, também, a beleza e o luxo năo serem propriamente atributos já conquistados, mas pontos de partida, adereços naturais, para a conquista dos seus verdadeiros atributos. Importa que seja constatada sua trajetória: da beleza à fortaleza.

18 - No sêculo VII d.C., o poeta Bharțhari - apontando para a conservaçâo dessa visăo, dirá num poema (traduçăo minha):

"Nâo tenho dotes de ator, náo sou um bưfáo chistoso, năo sou um músico iluminado nem um cortesăo ardiloso. Que lugar, entấo, na Corte para alguém como eu deve haver se nem ao menos sou uma jovem e atraente muther?" 
Em outras palavras, a açăo (a narrativa) - a precariedade da vida - apenas conforma, para o homem, suas prerrogativas; em relaçáo à mulher, todavia, transforma-as, configurando-a definitivamente complexa. Caracterizaçăo e narraçăo nâo săo, assim. excludentes: a caracterizaçăo de ambas as personagens in-forma dados definitivos (iniciais $=$ finais) para o homem e transitórios para a mulher, a narraçăo é um contraponto para a caracterizaçăo, pois que completa com outros dados, desvendando a mulher, aquele retrato idealizado, certamente exigido pela sua celebraçăo/consideraçåo no interior das castas dominantes. Uma mulher inferior (como dizem os historiadores, de olho no conteúdo dos textos) apenas porque năo ocupa posiçáo polticica de mando; mas seguramente ao lado do homem, por direito conquistado (năo propriamente concedido), instituldo por sua trajetória pela vida do homem.

Foi assim que o método de abordagem lingülstico-retórica me ajudou a reconsiderar as afimaçర్es sempre frágeis dos historiadores a respeito da condiçáo da mulher $\theta$ do homem na sociedade indiana épica de expressão literária sånscrita. O homem existe cristalizado de antemão: o conceito que dele se faz, mesmo que ele perca o reino num jogo de dados e se dobre, não muda nunca; a mulher, a princlpio apenas belissimamente linda, conquista sua força ao longo de sua vida (sem que, em momento algum, se coloque a questao da matemidade). Atitude patemalista (alguns diriam machista) ou idealizante ou até mesmo feminista, não importa discutir aqui o móvel dessas qualificaçóes - sob o risco de se ser novamente "impressionista". O fato é que a condiçáo social da mulher é pensada de maneira mais complexa que a do homem (não se trata propriamente de uma questão de "ambigüidade") e a formalização textual de sua $\rho$ osição o demonstra, mais claramente do que o exame dos manuais de história ou da literatura, que se apegam apenas ao conteúdo.

Um exame detalhado dos dois excertos (um trabalho etimológico, imagético, estillstico, m(tico, etc.) - um exame que não pude fazer aqui - com certeza levaria a uma argumentaçáo mais aprofundada. Bastou-me, no entanto, tentar mostrar que o método utilizado ultrapassa em muito o simples "espetamento manfaco do texto em garfos" com que I.N. Salum se refere aos seus esquemas: interessa-me, sobretudo - porque me parecem ser essas a finalidade $\theta$ a funçăo primordiais desse método -, levar a forma espetada à boca para apreciar o que a forma oculta ${ }^{19}$.

19 - Os dísticos 5 a 9 , intemediários entre as caracterizaçóes de Nala e Damayant, relatam o modo pelo qual o pai desta, Bhima (também um räjan, igualado resumidamente a Nala com um tathaiva "exatamente assim"), teve 4 filhos. Nos esquemas 1 e 2, as chaves $x$ ligam-se por melo desse relato; as chavos xx llgam-se à continuaçáo da narrativa. 
ESOUEMA 1.1

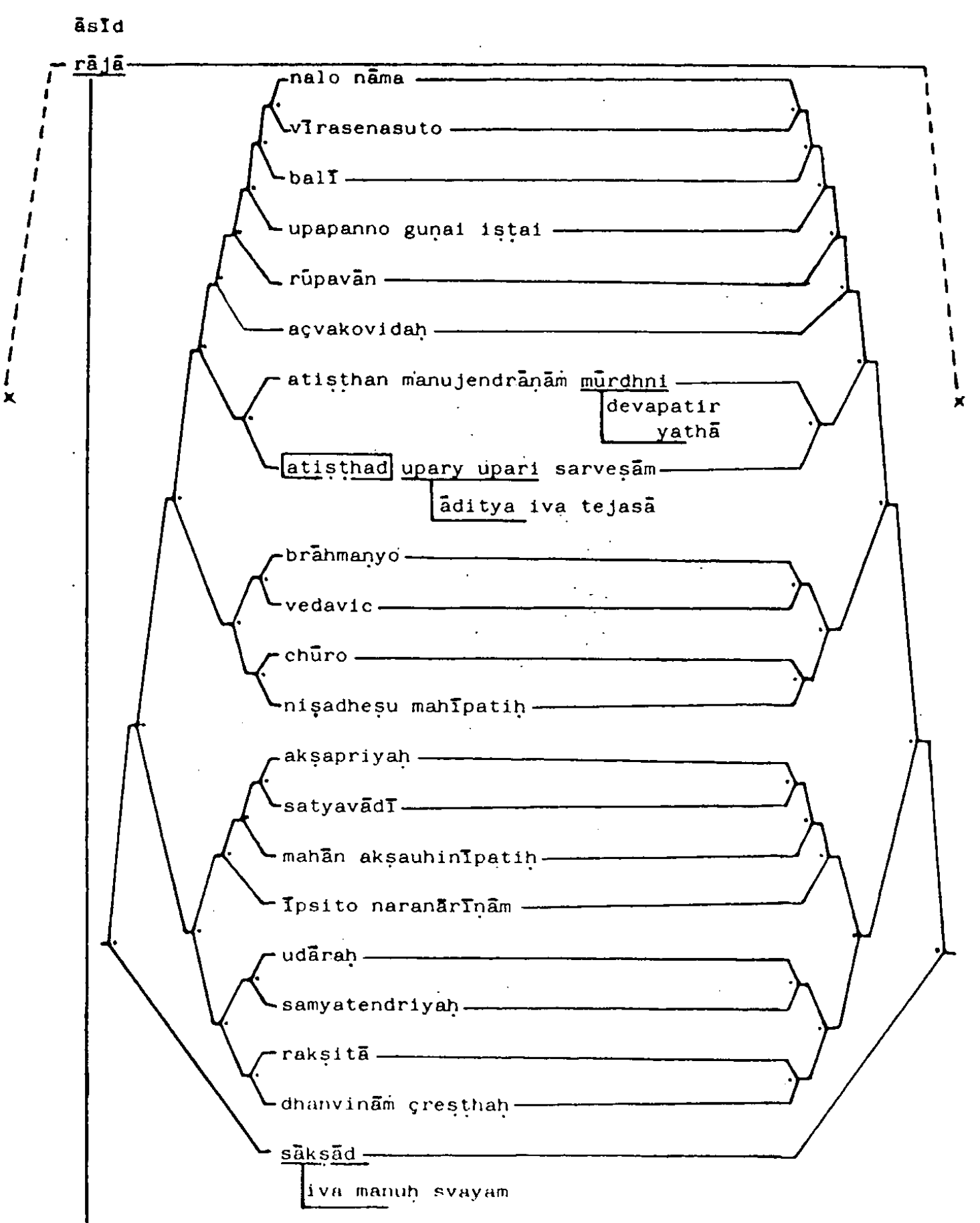


ESOUEMA 1.2

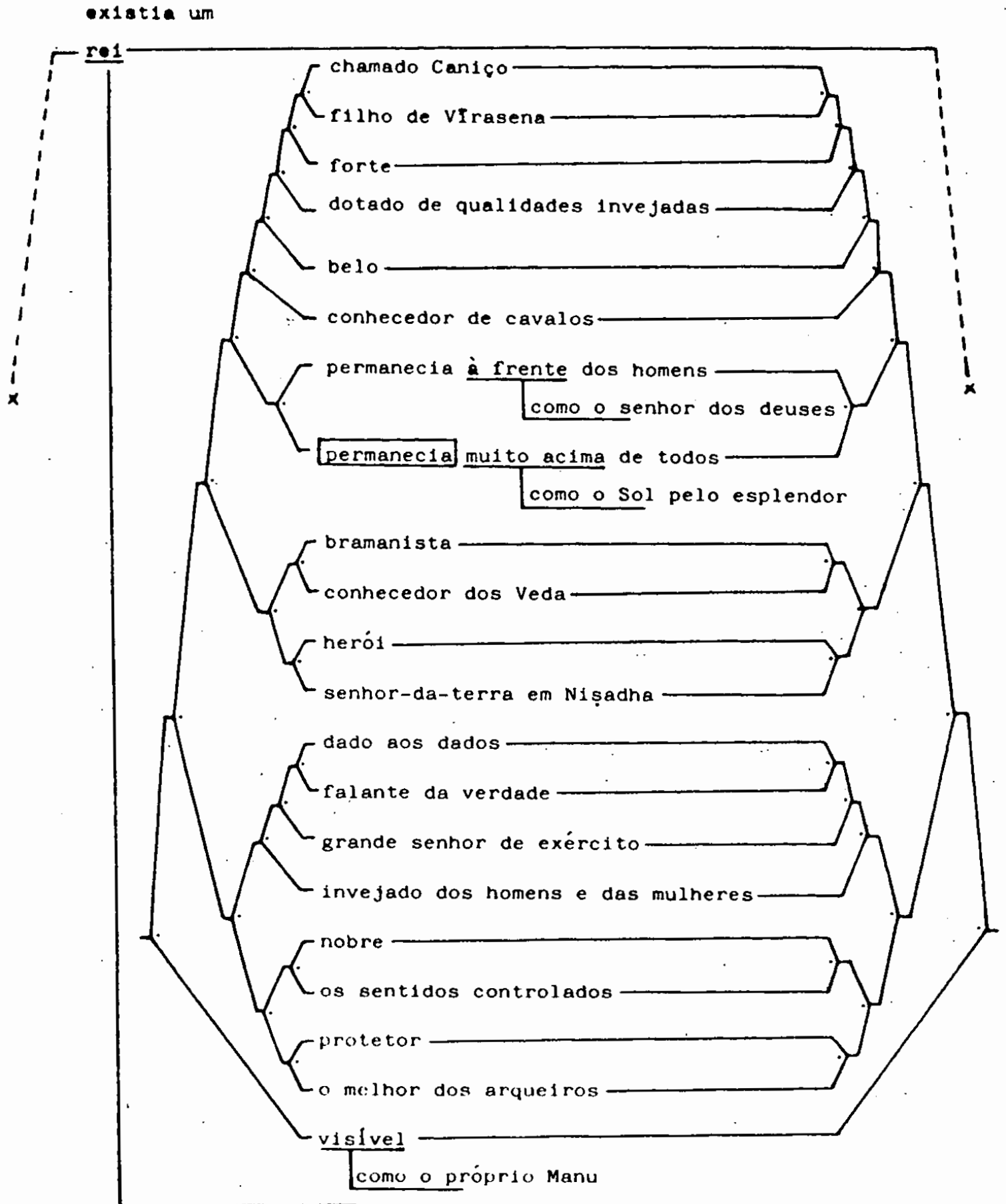


ESQUEMA 2.1

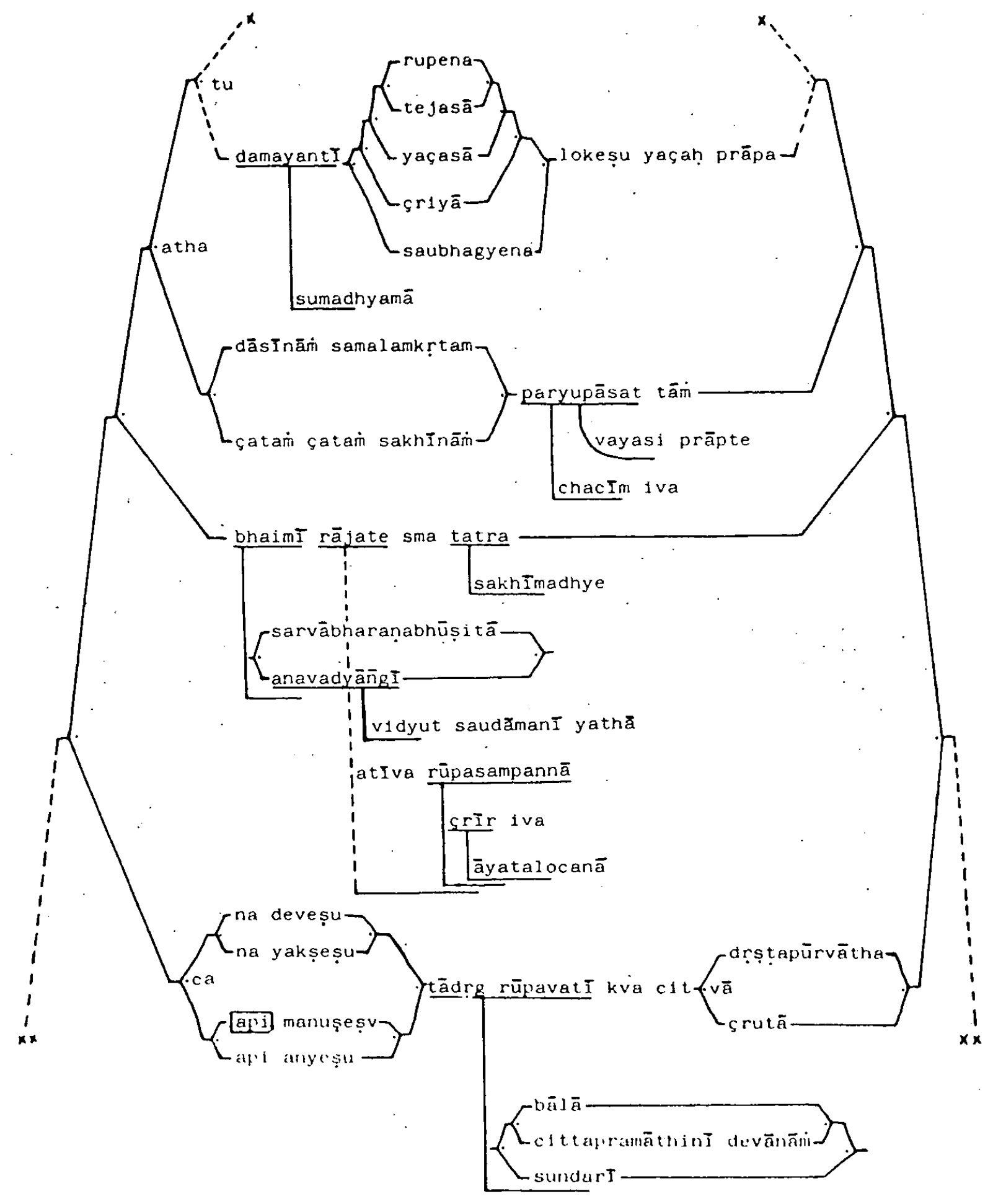




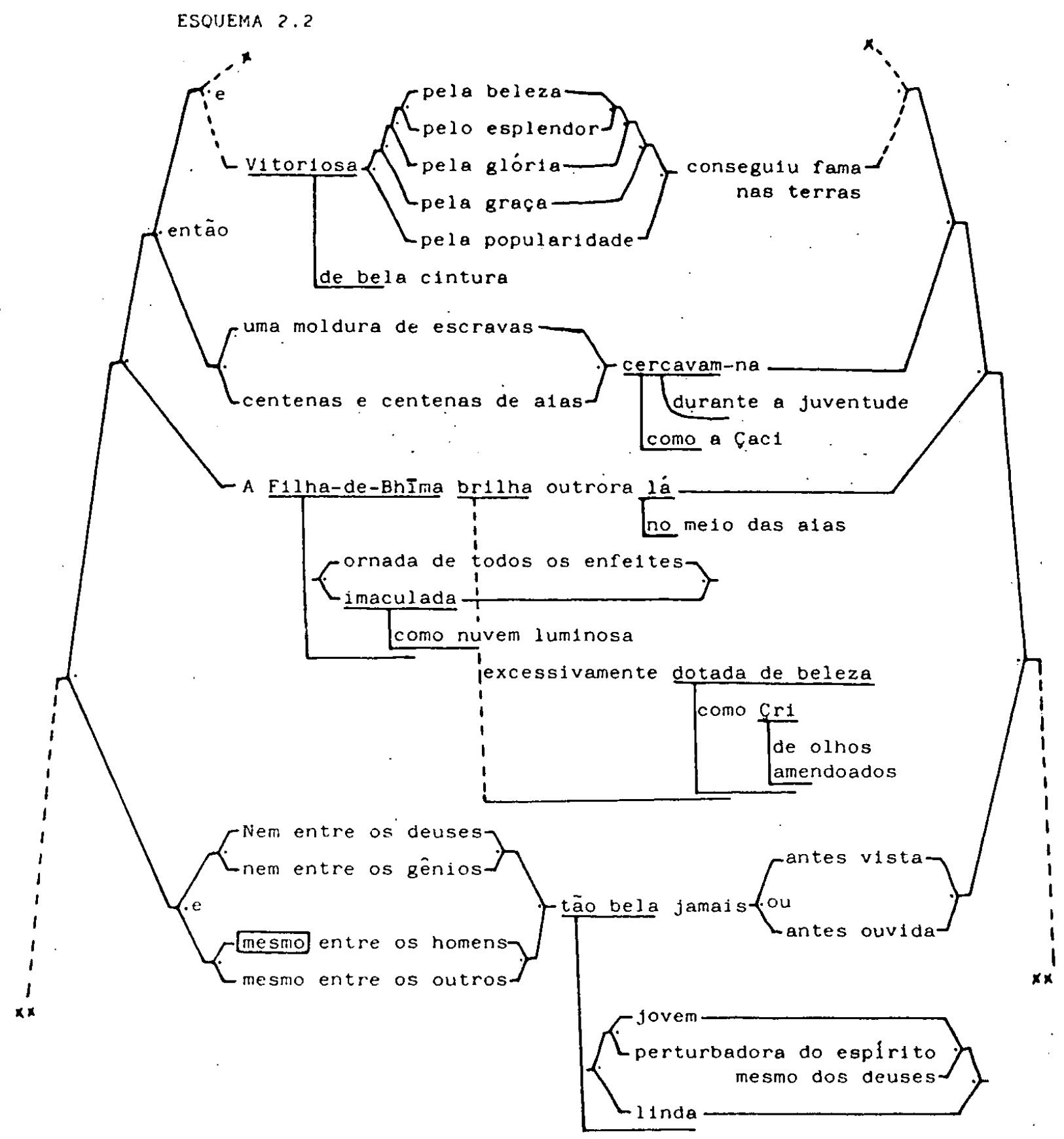




\section{INDICAÇȦO BIBLIOGRAFICA}

LANMAN, C.R. A Sanskrit Reader. Harvard, University Press, 1947.

PABON S. DE URBINA, J.M. Dicionario griego-espafiol Barcelona,Bibliograf, 1970.

SALUM, I.N. Camoes em tres lances. Camoniana, Sáo Paulo, III: 153-77 + 10 esquemas, 1971.

-_- Abordagem sintático-estillstica de um texto. Săo Paulo, ed. do Autor, 1971.

-_. Os sonetos da Infanta. Littera, Rio de Janeiro, 4: 8-25, 1972.

--- Decomposição, recomposição e análise crftica de um texto. Lingua e Literatura, Săo Paulo, 1: 9-41, 1972.

- Estudo sintático-estillstice de "Caçada de paca", crónica de Rubem Braga Săo Paulo, ed. do Autor, 1972.

Abordagem sintático-semántica de texto. Săo Paulo, ed. do Autor, 1972.

Abordagem sị̂ntático-semântica do texta. São Paulo, ed. do Autor, 1973.

A lição do texto. Rev. da Fac. de Educaçăo, Săo Paulo, 1: 43-62, 1975.

Abordagem sintático-semântica do texta Săo Paulo, ed. do Autor, 1978.

Abordagem lingũistico-retọrica do texto. São Paulo, ed. do Autor, 1979. 